\title{
COINTEGRATION BETWEEN EXCHANGE RATE AND INTEREST RATE DIFFERENTIAL: THE CASE OF PAK RUPEE/US DOLLAR
}

\section{Dr.Anwar Ali Shah G.Syed}

Prof. of Business Administration \&

Pro-Vice Chancellor-Sindh University-Dadu Campus

$$
\text { FaizM.Shaikh }
$$

Assistant Professor-SZABAC-Dokri-Larkana

Sindh-Pakistan

Email:faizanmy2000@hotmail.com

\section{Abdul Sattar Shah}

Assistant Professor

IBA-University of Sindh-Jamshoro

\section{Muhammad Akram}

Student of Iqra university Islamabad campus

Email: akramfsd@yahoo.com

\begin{abstract}
Empirical literature is inconclusive whether a relationship exists between Interest Rate Differential and exchange rate. However, theoretical literature suggests that such positive relationship exists between these variables. Monthly interest rate data between Pakistan and USA from Jan 2001 to December 2010 was taken and co-integration technique was applied to empirically test the relationship between both variables. The results show no relationship exists between these variables. This results supports the findings of previous studies of Edison and Pauls (1993) and Shah,A and Saeed Ur Reham (2010).
\end{abstract}

Key words: exchange rate; interest rate differential.

\section{Council for Innovative Research}

Peer Review Research Publishing System

Journal: International Journal Of Management \& Information Technology

Vol . 10, No 5

editorsijmit@gmail.com

$\underline{\text { www.ijmit.com }}$ 


\section{Introduction}

In this era of globalization, small and weaker economies like Pakistan are facing the challenge of opening up their markets for global products; otherwise they may face alienation and possible international sanctions. In the open market system, a country needs foreign currency to get foreign goods. So in this background, exchange rates have become critical macroeconomic indicator to judge the health of an economy.Strong local currency in relation to foreign currency makes imports/debts of the country cheaper. Conversely, weak local currency causes exports of the country cheaper abroad, hence increasing the demand for local currency abroad. For multinational corporations exchange rate is critical to correctly evaluate the performance of their investments. Hence the exchange rate is the price of foreign currency in term of local currency; like other prices, Foreign exchange rate keeps varying in response to demand and supply forces. Exchange Rate could be fixed or flexible. Under fixed exchange rate regime, foreign exchange rate is set by the central bank; whereas, in flexible exchange rate system, exchange rate is set by the demand and supply forces.Pakistan went through different phases of exchange rate regimes. Rupee was pegged to Pound Sterling from 1947 to 1972. Later it was pegged to US Dollar and then made floating. At present, it is floating and largely depends on the demand and supply forces. Exchange rates are influenced by a number of factors, including inflation rate differentials, interest rate differentials, current account deficits, public debt, terms of trade, political stability and economic performance.

Out of these factors, interest rate is the one that can be varied more easily by the governments, through central bank,to influence the Exchange rate. From October 2007 to November 2009, Pak Rupee was devalued by $38 \%$ against US Dollar. During this period, interest rates in US reached to its lowest $(0.05 \%)$, while Interest Rates in Pakistan were $13 \%(260$ times more than US). Impact of high interest rate on Pakistani Banking Sector was very positive. When banking sector around the globe was passing through a very critical phase - with number of mergers, acquisitions, bankruptcies were being witnessed, Pakistani banking sector was showing profits.Despite delinking of Pak Rupee from US Dollar, Exchange Rate between Pak Rupee/US $\$$ is still very critical to Pakistan. Almost all Foreign Trade and Foreign Debts are denominated in US \$. So Rupee/\$ exchange rate bears huge impact on Pak Economy.

Objective of this paper is to investigate the impact of Interest Rate Differential (defined as the "home" country's interest rate minus that of a "foreign" country) on exchange rate (defined as the price of the foreign currency in terms of the home currency) of Pak Rupee/US \$.

The paper is organized as follows: section II deals with literature review, Section III with Methodology, section IV with results and section $V$ with discussion and conclusion.

\section{Literature Review}

Out of other macroeconomic variables, interest rate and exchange rate are closely related. Higher nominal interest rate at home indicates predication of inflation in future and negatively affects the local currency. However, rise in real interest rate attracts foreign capital into the country, increasing the demand of local currency, and, consequently, appreciating the exchange rate for local currency.

In past, efforts were made to keep exchange rate fixed to make it predictable and stable. But over the years, it was proved that such efforts did more harm than good. So, like other commodities, price of local currency in terms of other currency exchange rate, was mostly left onthe forces of demand \& supply, making it volatile and less predictable. Other macroeconomic variables like inflation rate, current account balance, political and economic stability, law and order, trade terms etc. influence the exchange rate. But these variables cannot be easily manipulated. Hence, it is common for the governments to influence the exchange rate through variations in interest rates (Kim and Roubine, 2000). The central bank, in short run, can set the exchange rate, but in long run the rate is determined by market forces. (Dominguez, 2006). Economic news relating to macroeconomic variables, like interest rates, inflation etc. have positive/negative effect on local currency (Ehrmann and Fratzxcher, 2005).Robust long-run relationship was found between real interest rate differential and real exchange rate of Malaysian Ringgit and US Dollar (Beng and Ying, 2000). Information regarding macroeconomic variables is expressed in two broad terms i.e. strong or weak. When the overall health of economy is good, it is said that macroeconomic variables are strong and vice versa. In short run, rise in therealinterest rate appreciates the local currency when other variables are strong. In long run, however, there is co-movement in interest rate and exchange rates. (Fausta et al, 2007).In a recent study it was observed that relationship between interest rate and exchange rate is negative in short run, because of sticky prices, while it remains positive in long run due to price flexibility ( Hacker, Kim and Mansson, 2010).Another recent empirical study attempting to observe the relationship between interest rate/inflation rate upon exchange rate of Pak Rupee and UK Pound Sterling, it was concluded that there exists significant but negative relation between interest rate and exchange rate of Pak and US (Ramiz ,AteeqandRaoof 2010).The difference in real interest rates, in the presence of positive macro-economic indicators, attracts the capital inflow, raising the demand for domestic currency and appreciating the exchange rate for local currency ( Girard, . Kiymaz, 2009).Some researchers believe that interest rate is one of the most powerful determinants of exchange rate (Suthar, 2008; Haque and Brumm, 2008). However, in Central Asian economies, that are predominantly cash-based, it is very hard to measure the impact of interest rate on exchange rate (UNODC, Oct 2009).

In emerging markets, impact of interest rate on exchange rates is not significant because of poor monetary policies and less competency of financial markets. Long term interest rate and exchange rate does not have strong role in economies like Poland.(Sarwa, 2006).

One study measuring impact of changes in interest rate on exchange rate between US and Pak, by using simple regression model, concluded that although there exists positive relationship between interest rate and exchange 
variations, but it is not much significance. It has low explanatory power to predict the exchange rate (Khan, 2009). There is low co-movement between interest rateand exchange rate in a country having strong monetary structure, so the comovement depends on the monetary structure of the relative country (Holtemoller, 2005). And another very important factor is time span. In short run, even negative relation was observed between interest rate and exchange rates (Ray, 2008. Hacker, Kim and Mansson, 2010).

Results of studies using panel data for testing cointegration between real interest rates and real exchange rate were inconclusive, because without taking other influencing variables into consideration it is difficult to find some clear relationship between these two. Short run models show that the relationship between real exchange rate and real interest rate is non-monotonic (Narayan and Smyth, 2006). Long run relationship between the world interest rate and exchange rate depends upon the net financial position of the domestic country (Gente and Leon-Ledesma, 2006).

In view of the above literature analysis, it appears that although there is positive relationship between interest rate and exchange rate, its degree varies from economy to economy depending upon the stability of economy. Moreover, it shows different impacts in short and long runs. In short run it may turn negative. And as it is not the only explaining factor, so it is desirable to examine it in combination with other macro-economic indicators, especially the inflation rate. However, according to many economists, it is yet very powerful and easily manipulateable tool that is quite frequently used by governments to influence the exchange rate.

\section{Data \&Methodology}

Monthly Data from 2001 to 2010 was used. Kibor was used to take Interest Rates in Pakistan (data source Business Recorder), Libor was used to take interest rates in US (data source Fannie Mae and British Bankers' Association websites). Exchange rate data was taken from Yahoo Finance. Data was analyzed by taking the following steps:

1. Before going for formal analysis, stationarity of the data was checked by using Augmented Dickey Fuller test. ADF makes the series stationary by taking difference in case it is non-stationary at level. The ADF equation is as follows:

$\Delta \mathrm{RER}_{\mathrm{t}}=\beta_{1}+\beta_{2} \mathrm{t}+\sigma \mathrm{RER} \mathrm{R}_{\mathrm{t}-1}+\alpha_{\mathrm{i}} \sum_{\mathrm{i}=1}^{m} \Delta \mathrm{RER}_{\mathrm{t}-\mathrm{i}}+\varepsilon_{\mathrm{t}}$

$\Delta I R D_{t}=\beta_{1}+\beta_{2} t+\sigma I R D_{t-1}+\alpha_{i} \sum_{i=1}^{m} \Delta I R D_{t-1}+\varepsilon_{t}$

(REER stands for Real Effective Exchange Rate, whereas IRD is Interest Rate Differential.)

2. After making the data stationary by applying ADF, we checked the co-integration by Hypothesis I:

Positive / Negative relationship exists between Interest Rate Differential and Exchange Rate.

\section{Hypothesis II:}

There is no relationship exists between Interest Rate Differential and Exchange Rate.

\section{Statistical Findings}

Augmented Dickey-Fuller (ADF) test for Interest Rate Differential and Exchange Rate

Table 1:

\begin{tabular}{|c|c|c|c|c|c|c|c|}
\hline \multicolumn{8}{|c|}{ Unit Root Analysis of Exchange Rate } \\
\hline At Level & & t-Statistic & Prob. $^{*}$ & At First Difference & & t-Statistic & Prob.* \\
\hline $\begin{array}{l}\text { Augmented Dickey- } \\
\text { Fuller test statistic }\end{array}$ & & -1.97247 & 0.2986 & $\begin{array}{l}\text { Augmented Dickey- } \\
\text { Fuller test statistic }\end{array}$ & & -4.47702 & 0.0004 \\
\hline \multirow[t]{3}{*}{ Test critical values: } & $\begin{array}{l}1 \% \\
\text { level }\end{array}$ & -3.48705 & & Test critical values: & $\begin{array}{l}1 \% \\
\text { level }\end{array}$ & -3.48705 & \\
\hline & $\begin{array}{l}5 \% \\
\text { level }\end{array}$ & -2.88629 & & & $\begin{array}{l}5 \% \\
\text { level }\end{array}$ & -2.88629 & \\
\hline & $\begin{array}{l}10 \% \\
\text { level }\end{array}$ & -2.58005 & & & $\begin{array}{l}10 \% \\
\text { level }\end{array}$ & -2.58005 & \\
\hline
\end{tabular}

For Cointegration analysis, time series data should be stationary. So in first step stationarity of data was tested. Data was not stationary at levels. Because t-value is greater than critical value at $5 \%$ level. However, first differences of the series are stationary because at this level the t-value is less than the critical value at $5 \%$. So we say that series are integrated of order one I(1). 
Table 2:

\begin{tabular}{|c|c|c|c|c|c|c|c|}
\hline \multicolumn{8}{|c|}{ Unit Root Analysis of Interest Rate Differential } \\
\hline At Level & & t-Statistic & Prob.* & At First Difference & & & \\
\hline & & & & & & t-Statistic & Prob. ${ }^{*}$ \\
\hline $\begin{array}{l}\text { Augmented Dickey- } \\
\text { Fuller test statistic }\end{array}$ & & -1.82607 & 0.3664 & & & & \\
\hline Test critical values: & $\begin{array}{l}1 \% \\
\text { level }\end{array}$ & -3.48606 & & $\begin{array}{l}\text { Augmented Dickey- } \\
\text { Fuller test statistic }\end{array}$ & & -9.01753 & 0.0000 \\
\hline & $\begin{array}{l}5 \% \\
\text { level }\end{array}$ & -2.88586 & & Test critical values: & $\begin{array}{l}\% \\
\text { level }\end{array}$ & -3.48655 & \\
\hline & $\begin{array}{l}10 \% \\
\text { level }\end{array}$ & -2.57982 & & & $\begin{array}{l}5 \% \\
\text { level }\end{array}$ & -2.88607 & \\
\hline & & & & & $\begin{array}{l}10 \% \\
\text { level }\end{array}$ & -2.57993 & \\
\hline
\end{tabular}

For Cointegration analysis, time series data should be stationary. So in first step stationarity of data was tested. Data was not stationary at levels. Because t-value is greater than critical value at $5 \%$ level. However, first differences of the series are stationary because at this level the t-value is less than the critical value at $5 \%$. So we say that series are integrated of order one $\mathrm{I}(1)$.

Table 3: Co-integration Analysis (Trace statistics)

\begin{tabular}{|l|l|l|l|l|}
\hline & Trace Stat. & $\begin{array}{l}\text { Critical Value } \\
\mathbf{5 \%}\end{array}$ & Probability & Remarks \\
\hline IRD - & 7.874639 & 15.49471 & 0.4789 & \\
Exchange Rate & 2.973546 & 3.841466 & 0.0846 & No Cointegration \\
\hline
\end{tabular}

Table 3 shows that no co-integration exists between interest rate differential and exchange rate. At $5 \%$ level, because Critical Value is greater than trace statistics value, and probability is also greater than $5 \%$. So we reject the hypothesis $\mathrm{H}_{1}$ and accept the alternative hypothesis.

Table 4: Co-integration Analysis (Max-eigen value statistics)

\begin{tabular}{|l|l|l|l|l|}
\hline & Trace Stat. & $\begin{array}{l}\text { Critical Value } \\
\mathbf{5 \%}\end{array}$ & Probability & Remarks \\
\hline Interest Rate & 4.901093 & 14.2646 & 0.7543 & No Cointegration \\
$\begin{array}{c}\text { Differential } \\
\text { Exchange Rate }\end{array}$ & 2.973546 & 3.841466 & 0.0846 & \\
\hline
\end{tabular}

Table 4 shows that no co-integration exists between interest rate differential and exchange rate. At $5 \%$ level, Critical Value is greater than trace statistics value, and probability is also greater than $5 \%$. So we reject the hypothesis $\mathrm{H}_{1}$ and accept the alternative hypothesis.

\section{Conclusion:}

This paper attempted to empirically test the relationship between Interest Rate Differential and Exchange rate between Pakistan and USA by using Cointegration approach taking monthly data from January 2001 to December 2010. Cointegration technique was applied. Our empirical results conclude "No Cointegration" was found between these two variables. This result supports the results of previous researchers like Edison and Pauls (1993) and Shah, A and Saeed Ur Rehman (2010). It is recommended that other macroeconomic variables like inflation, unemployment rate, foreign reserves, GDP, industrial growth, trade balanceetc.should also be taken into consideration along with IRD to explain the variations in Exchange Rate.

There are numerous reasons why no co-integration was found between IRD and Exchange Rate: like continuous fluctuations in exchange rates, political instability, high inflation rate in Pakistan as compared to US, instable monetary policies, low GDP growth, terrorism, weak foreign reserves, trade deficit, power crises in Pakistan etc. 


\section{References}

1. Beng, G.W.(1998) Exchange Rate and Interest Rate Differential: the Case of the Malaysian Ringgit/US Dollar, Applied Economics Letters, 16, 639-651.

2. Fausta, J., Rogersa, J. H., Wangb, S. B. and Wrightc, J. H. (2007), The high-frequency response

3. of exchange rates and interest rates to macroeconomic announcements, Journal of Monetary

4. Economics, Vol. 54, pp.1051-1068.

5. Gente, K. and Leon-Ledesma, M.A. (2006) Does the World Real Interest Rate Affect the Real Exchange Rate? The South East Asian Experience, J. Int. Trade \& Economic Development, Vol. 15, No. 4, 441-467.

6. Girard, E., and Kiymaz H.(2009). The Risk factors associated with investing in an emerging equity market during the EU membership process, The International Journal of Business and Finance Research, Volume 3, Number 1 , pp 1-18.

7. Hacker, R.S., Kim, H. and Mansson, K.(2010) The Relationship between Exchange Rate and Interest Rate Differentials - a Wavelet Approach, Centre of Excellence for Science and Innovation Studies, CESIS Electronic Working Paper Series, Paper No. 217.

8. Haque, M.A., and Brumm J. (2008). Macro variables in determining the exchange of the U.S. Dollar and major currencies, Proceedings of the Academy for Studies in International Business, Volume 8, Number 2, Presented at: Allied Academies International Conference, Reno NV.

9. Holtemoller, O. (2005), Uncovered interest rate parity and analysis of monetary convergence of

10. potential EMU accession countries, IEEP, Vol. 2, pp. 33-63

11. Khan, S.A., Empirical Study on Impact of Interest Rate on Exchange Rate, http://ssrn.com/abstract=1625492

12. Kim, S. and Roubini, N. (2000), Exchange rate anomalies in the industrial countries: A solution

13. with a structural VAR approach, Journal of Monetary Economics, Vol. 45, pp. 561-58

14. Narayan, P.K. and Smyth.R. (2006) The Dynamic Relationship between Real Exchange Rate, Real Interest Rates and Foreign Exchange Reserves: Empirical Evidence from China, Applied Financial Economics, 16, 639651.

15. Ray, H. (2008), Dynamic Interactions of Exchange Rates, Stock Prices and Macroeconomic

16. Variables in India, Thelcfai University Press, India

17. Rehman, R., Rehman, M.A., Raoof, A. (2010) Causal Relationship between Macroeconomic Variable and Exchange Rate, International Research Journal of Finance and Economics, ISSN 1450-2887, Issue 46.

18. Serwa, D. (2006). Do emerging financial markets react to monetary policy announcements? Evidence

19. from Poland, Applied Financial Economics, 16, pp 513-523.

20. Suthar, M.H. (2008). Bank Rate and Interest Yield Differentials as Determinants of Foreign Exchange Rate in India, The Icfai Journal of Monetary Economics, Vol. VI, No. 2, pp. 43-49. 